\title{
Interaction of Fusarium graminearum and F. moniliforme in Maize Ears: Disease Progress, Fungal Biomass, and Mycotoxin Accumulation
}

\author{
L. M. Reid, R. W. Nicol, T. Ouellet, M. Savard, J. D. Miller, J. C. Young, D. W. Stewart, and A. W. Schaafsma
}

First, second, third, fourth, and seventh authors: Eastern Cereal and Oilseed Research Centre, Central Experimental Farm, Agriculture and Agri-Food Canada, Ottawa, Ontario, Canada K1A 0C6; fifth author: Carleton University, Department of Chemistry, Ottawa, Ontario, Canada K1S 5H6; sixth author: Food Research Program, Southern Crop Protection and Food Research Centre, 43 McGilvray Street, Guelph, Ontario, Canada N1G 2W1; and eighth author: Ridgetown College, University of Guelph, Ridgetown, Ontario, Canada N0P 2 C0. Accepted for publication 10 July 1999.

\begin{abstract}
Reid, L. M., Nicol, R. W., Ouellet, T., Savard, M., Miller, J. D., Young, J. C., Stewart, D. W., and Schaafsma, A. W. 1999. Interaction of Fusarium graminearum and $F$. moniliforme in maize ears: Disease progress, fungal biomass, and mycotoxin accumulation. Phytopathology 89:1028-1037.

To investigate the interaction between two major ear-rotting pathogens, maize ears were inoculated with either Fusarium graminearum, F. moniliforme, or an equal mixture of the two. Silk and kernel tissues were periodically harvested throughout the growing season so that a time course of the experimental variables (disease severity, ergosterol content, fungal DNA content, and mycotoxin concentration) could be recorded. Over the 3 years tested (1992 to 1994), the highest levels of disease and ergosterol were found in the $F$. graminearum treatment, followed by the mixture treatment $(F$. graminearum plus $F$. moniliforme $)$ and, finally, the $F$. monil-

iforme treatment. Kernel ergosterol content and disease rating were correlated for both pathogens, but the highest correlation coefficients were obtained in the $F$. graminearum treatment. The DNA analysis revealed that, in the mixed inoculum, $F$. moniliforme had a greater growth rate than did $F$. graminearum. In 1994, appreciable $F$. moniliforme from natural inoculum was found in the $F$. graminearum treatment. Fumonisin $\mathrm{B}_{1}$ levels did not differ between the $F$. moniliforme treatment and the mixed inoculum treatment. The effect of temperature on the growth rate of the two species explained some of the field results, with temperatures in the silks being more favorable to F. moniliforme. Data on the growth rate on silks obtained by the incorporation of radiolabeled precursor to ergosterol demonstrated that $F$. graminearum was able to grow well at 26 to $28^{\circ} \mathrm{C}$, whereas $F$. moniliforme grew well over a broader range, including at higher temperatures.
\end{abstract}

The major ear rot diseases of maize (corn, Zea mays L.) in Canada are caused by Fusarium spp. Three species of Fusarium are predominantly responsible for the disease: $F$. graminearum Schwabe (teleomorph = Gibberella zeae (Schwein.) Petch), F. moniliforme J. Sheldon $(=F$. verticillioides (Saccardo) Nirenberg, teleomorph $=$ G. fujikuroi (Sawada) Ito in Ito \& K. Kimura), and F. subglutinans (Wollenweb. \& Reinking) P.E. Nelson, T.A. Toussoun, \& Marasas (teleomorph $=$ G. subglutinans (E. Edwards) P.E. Nelson, T.A. Toussoun, \& Marasas) (59). All three species can produce mycotoxins in the grain. The toxins of most concern are those produced by $F$. graminearum (deoxynivalenol [DON] and zearalenone) and F. moniliforme (fumonisin $\mathrm{B}_{1}\left[\mathrm{FB}_{1}\right]$ ). The trichothecene toxin DON causes feed refusal and decreased weight gain in swine (43). This toxin is also an immunosuppressant and thus predisposes animals to other diseases and masks underlying toxicosis (42). Zearalenone causes reproductive problems including reduced litter size, swine estrogenic syndrome, and male infertility (43). $\mathrm{FB}_{1}$ causes equine leukoencephalomalacia (20), porcine pulmonary edema (14), and liver cancer in rats (10). Fumonisins have also been associated with human esophageal cancer (19).

F. graminearum (causal agent of Gibberella ear rot) produces a pink- to reddish-colored mold on kernels that usually spreads from the tip of the ear downward or outward from an insect wound. $F$. moniliforme (causal agent of Fusarium ear rot) produces a whitishcolored mold growth that tends to be scattered on the ear. Reports indicate that not all F. moniliforme-infected kernels are symptomatic $(2,21)$. It has been suggested that this fungal species can be systemic in the maize plant and ubiquitous in nature $(28,34)$.

Corresponding author: L. M. Reid; E-mail address: reidl@em.agr.ca

Publication no. P-1999-0913-02R

(C) 1999 The American Phytopathological Society
The entry of Fusarium spp. into maize ears can occur through wounds caused by insects or birds $(1,56)$ or by the growth of mycelium down silks to the kernels and cob (rachis) from spores germinating on the silks $(17,22,54)$. F. graminearum requires succulent silk tissue, less than 8 to 10 days old, for infection $(8,46,55,58)$. In contrast, colonization of silks by $F$. moniliforme occurs more frequently after the onset of silk senescence $(15,16)$.

The best way of controlling Fusarium spp. ear rots is the development of host-plant resistance. Confounding the attempt to breed resistance into maize for both fungal species is the lack of knowledge on how $F$. graminearum and $F$. moniliforme interact in maize ears. The approach favored by some breeders, using a "cocktail" of Fusarium spp. to select maize genotypes with resistance to multiple species, is questionable because of possible interspecific competition and varying environmental conditions, especially temperature. Although there is overlap between the temperature ranges for growth of $F$. moniliforme and $F$. graminearum, the diseases of maize caused by these two species are favored by different conditions. F. graminearum requires periods of warm temperatures with persistent wetness during July and August (silking and early kernel development) $(23,28,54,57)$. Thus, Gibberella ear rot is associated with growing regions in Illinois, New York, Michigan, and Ontario (28). F. moniliforme occurs during higher temperatures and drier years $(40,51,59)$ and is associated with warm, dry conditions of the subtropics and dryland maize production. In Ontario, studies of Fusarium spp. on maize show increased recovery of $F$. moniliforme during warmer years (temperatures $\left.>25^{\circ} \mathrm{C}\right)(29,30,59)$.

Competition between fungi that occupy nominally the same econiche has two often-intertwined features: competitive exploitation and interference competition (60). Competitive exploitation refers to the ability of fungi to consume nutrients before other species that might be present, whereas interference competition involves a chemical or behavioral trait that limits the access of the 
competing fungus to resources. For plant-pathogenic species, a third variable, aggressiveness, is important. One component of competitive exploitation is response to temperature. There are data on the temperature response of some strains of $F$. moniliforme and $F$. graminearum $(6,26,27,63)$. However, these data are of limited value in predicting the outcomes under field conditions because they were completed on artificial media under laboratory conditions and strains vary from different climates.

F. moniliforme has been reported to suppress the growth of other maize ear fungi including $F$. graminearum and Aspergillus flavus Link:Fr. $(17,48,62,65,66)$. Negative associations between the occurrence of $F$. moniliforme with both $F$. graminearum and $F$. subglutinans have also been reported $(25,48)$.

The objective of this study was to investigate the interaction between $F$. graminearum and $F$. moniliforme in silk channel-inoculated maize ears by monitoring the progress of disease symptoms, ergosterol, mycotoxins (DON and $\mathrm{FB}_{1}$ ), and species-specific DNA content. In addition, studies were made of the growth rate on silk tissue harvested from the field of the two species to understand the effect of temperature on the data obtained.

\section{MATERIALS AND METHODS}

Inoculation and harvest. From 1992 to 1994, a single $F$. graminearum- and F. moniliforme-susceptible maize hybrid (DeKalb DK415) was planted in a $4 \times 12$ factorial experiment arranged in split-plot design with three blocks at the Central Experimental Farm in Ottawa, Ontario. Four inoculation treatments $(F$. graminearum [G], F. moniliforme [M], both species simultaneously [GM], and a sterile water control) were randomized among the main plot units so that each consisted of 12 single-row subplot units consisting of 12 harvest times $(2,4,6,8,10,12,14,18,22,35,49$, and 63 days postinoculation). In 1992 and 1993, an additional five subplot harvest dates $(1,3,5,20$, and 26 days) were used. Each subplot unit consisted of 15 plants in a row (3.8 m long), with $76 \mathrm{~cm}$ between rows. The primary ears of the center 10 plants of each row were silk-inoculated.

A macroconidial suspension of $F$. graminearum was prepared as previously described $(46,47)$, using a single isolate, DAOM 180378. In the same manner, a suspension of $F$. moniliforme micro- and macroconidia was prepared from the isolate DAOM 195167. Both isolates were obtained from the Canadian Collection of Fungus Cultures (Agriculture and Agri-Food Canada, Ottawa, Ontario), were previously isolated from naturally infected maize ears, and have a moderately high level of aggressiveness compared with other isolates. Both isolates produced mycotoxins (DON and $\mathrm{FB}_{1}$ ) upon inoculation into maize ears. Individual plants were inoculated by injecting $2 \mathrm{ml}$ of a suspension $\left(5 \times 10^{5}\right.$ conidia per $\left.\mathrm{ml}\right)$ into the silk channel of the primary ear approximately 6 days after silk emergence $(46,47)$. For the simultaneous inoculation of a mixture of the two species, equal volumes of the suspensions $\left(5 \times 10^{5}\right.$ conidia per ml) were mixed just prior to inoculation. All inoculations were conducted within 1 to $2 \mathrm{~h}$ of each other. After inoculation, humid conditions were maintained by overhead sprinkler irrigation with 2 to $5 \mathrm{~mm}$ of water daily in the late afternoon for 4 weeks. Daily minimum and maximum temperatures were monitored by a data logger (model 21x, Campbell Scientific Inc., Logan, UT) located within the plot. The silk channel temperature of 12 plants was monitored by inserting thermocouples into the silk channels. Silk samples were removed each day, until the silk had dried out, to determine percent moisture.

At each harvest date, the 10 inoculated ears were hand-picked and husked (taking care to collect the silk), and the severity of ear rot symptoms was evaluated using a seven-class rating scale, in which $1=$ no infection, $2=1$ to $3 \%, 3=4$ to $10 \%, 4=11$ to $25 \%$, $5=26$ to $50 \%, 6=51$ to $75 \%$, and $7=>75 \%$ of the kernels exhibiting visible symptoms of infection, such as rot and pinkish- or white-colored mycelial growth (47). Harvested ears were bulked within each row and hand-shelled, and the cobs (rachises) were discarded. A scalpel was used to remove kernels from young ears. Each sample was mixed thoroughly to obtain a random distribution of the kernels, and a 350-g sample was freeze-dried for 5 days in a Pennwalt Stokes freeze-drier (Vacuum Epuipment, Philadelphia), after which a 50-g subsample was ground to a fine powder in a Retsch Ultra Centrifugal mill (type ZM1; Brinkman Instruments, Inc., Rexdale, Ontario) with a $0.75-\mathrm{mm}$ wire mesh. Subsamples were then taken for fungal biomass determination by ergosterol measurement and species identification using molecular analyses of DNA and mycotoxin (DON and $\mathrm{FB}_{1}$ ) analysis.

Ergosterol analysis. Ergosterol, a sterol found exclusively in fungal membranes (36), was used to measure fungal biomass (31, 50). Ergosterol was extracted as per Young (64) with slight modifications. A 50-mg subsample of the ground maize tissue was placed in 17-ml culture tubes along with $2 \mathrm{ml}$ of $\mathrm{MeOH}$ and $0.5 \mathrm{ml}$ of $2 \mathrm{M}$ $\mathrm{NaOH}$. The tubes were tightly closed with Teflon-lined caps, placed inside capped 500-ml plastic bottles, and irradiated in a microwave oven (Kenmore model \#8841; Sears Canada, Toronto, Ontario) at 50\% power (2,450 Mhz, 750 watts maximum output) for $20 \mathrm{~s}$ and, after approximately $5 \mathrm{~min}$, for an additional $20 \mathrm{~s}$. After cooling, the tubes were removed from the plastic bottles and the samples were neutralized with $1 \mathrm{M}$ aqueous $\mathrm{HCl}$ and treated with $2 \mathrm{ml}$ of $\mathrm{MeOH}$. The samples were partitioned with $3 \times 4 \mathrm{ml}$ of pentane, and the extracted top pentane layers were combined in 8-ml glass vials and evaporated in a sand bath at 50 to $60^{\circ} \mathrm{C}$. The extracts were then redissolved in pentane and passed through a 13 CR PTFE membrane syringe filter, $0.45-\mu \mathrm{m}$ pore size (Acrodisc; Gelman Scientific, Ann Arbor, MI), into 2.0-ml glass vials and then evaporated to dryness.

Quantification of ergosterol was made using high-performance liquid chromatography (HPLC). $\mathrm{MeCN} / \mathrm{MeOH} / \mathrm{H}_{2} \mathrm{O}$ (80:10:6) was pumped through a $250 \times 4.6-\mathrm{mm}$ Keystone Prism RP column $(5 \mu \mathrm{m}$, 100 A pore size; Keystone Scientific, Bellefonte, PA) at a flow rate of $2.0 \mathrm{ml} / \mathrm{min}$. The sample extract was dissolved in a known amount (50 to $1,000 \mu \mathrm{l}$, depending upon expected concentration of ergosterol) of ethyl acetate/pentane (1:1), and $25 \mu \mathrm{l}$ was injected into the column.

A Varian variable wavelength detector (\#2050; Varian, San Fernando, CA) was set at $282 \mathrm{~nm}$ for peak detection. Ergosterol retention time was used to identify peaks. Retention time and the detector's response (area counts per nanogram of ergosterol) were determined daily with an external standard. Confirmation of ergosterol in the sample was obtained using gas chromatographymass spectroscopy (GC-MS) and coinjection.

Molecular identification of fungal species and quantification of fungal biomass. Quantification of the fungal biomass for each species was done in two steps. First, a slot blot DNA hybridization assay was used to measure the total fungal biomass for the Fusarium spp. and other Hyphomycetes spp. present in the maize samples. Second, a polymerase chain reaction (PCR)-based assay was used to determine the ratio of the fungal species present in each sample. It has been shown that the relative ratio, not the yield, of a mixture of DNA templates is preserved with amplification $(12,33,37,39)$. Fungal biomass for each species in a sample was calculated as follows: total fungal biomass (pg of DNA per mg of tissue) $\times$ fraction of the species DNA in the PCR-amplified fungal fragment.

Total DNA was extracted from duplicate subsamples $(50 \mathrm{mg}$ each) as described by Möeller et al. (32). Fungal biomass quantification was conducted by slot blot DNA hybridization with the probe FG5B1L, which detects all Fusarium spp. and a number of other Hyphomycetes spp. (T. Ouellet, unpublished data). The use of the clone FG5B1L, a nuclear ribosomal DNA fragment present in multicopy in the fungal genome, as a probe increased by severalfold the sensitivity of detection of this hybridization assay (13). Prehybridization was overnight at $65^{\circ} \mathrm{C}$ in $5 \times 0.015 \mathrm{M}$ sodium citrate ( $\mathrm{SSC}, 1 \times \mathrm{SSC}$ is $0.15 \mathrm{M} \mathrm{NaCl}$ plus $0.015 \mathrm{M}$ sodium citrate), $\mathrm{pH} 7.0 ; 50 \mathrm{mM} \mathrm{NaPO}$; $0.1 \%$ sodium dodecyl sulfate (SDS); $5 \times$ Denhardt solution; and $250 \mu \mathrm{g}$ of denatured herring sperm DNA per ml. 
The hybridization, also overnight at $65^{\circ} \mathrm{C}$, was done in $1 \times \mathrm{SSC}$, $20 \mathrm{mM} \mathrm{NaPO}_{4}, 0.1 \%$ SDS, $1 \times$ Denhardt solution, $5 \%$ dextran sulfate, $100 \mu \mathrm{g}$ of denatured herring sperm DNA per ml, and the digoxigenin-labeled probe. After hybridization, the membranes were washed as suggested by the manufacturer (Biotrans; ICN Biomedicals, Inc., Costa Mesa, CA), using $0.1 \times \mathrm{SSC}$ and $0.1 \%$ SDS at $65^{\circ} \mathrm{C}$ for the final wash. The autoradiograms were scanned and analyzed using the Gel Print 2000i digital camera system and software (BioPhotonics Corporation, Dexter, MI). For quantification, the amount of fungal DNA in each maize sample was calculated by comparison with known fungal DNA controls present on the membranes.

The proportion of each Fusarium spp. present in the maize samples was determined by PCR assay using the same DNA extracts as above. A fragment of the nuclear large rDNA gene from fungi was specifically amplified using the primers LROR (45) and LR6 (5'CGCCAGTTCTGCTTACC $\left.3^{\prime}\right)$, which are located in conserved areas of the gene (45, public sequence databases). Amplified fragments were then digested with the restriction enzyme AvaI to generate species-specific DNA patterns. The enzyme used generated distinct banding patterns for the Fusarium spp. used in this study (data not shown). Banding patterns from infected samples were compared with those from pure fungal cultures for identification. When more than one fungal species was detected, the band intensities for the different species were measured by scanning and analysis of ethidium bromide-stained agarose gels with the Gel Print 2000i digital camera system and software.

Mycotoxin analysis. DON. A competitive direct enzyme-linked immunosorbent assay (CD-ELISA) determination of DON was conducted according to Sinha and Savard (52). Briefly, samples (1 g)

TABLE 1. Analysis of variance for disease severity after inoculation of the silk channel with Fusarium graminearum, F. moniliforme, or a mixture of the two species in 1992, 1993, and 1994

\begin{tabular}{|c|c|c|c|c|c|c|}
\hline \multirow[b]{2}{*}{ Source } & \multicolumn{2}{|c|}{1992} & \multicolumn{2}{|c|}{1993} & \multicolumn{2}{|c|}{1994} \\
\hline & $\mathrm{df}^{\mathrm{y}}$ & $\mathrm{MS}^{\mathrm{y}}$ & $\mathrm{df}$ & MS & $\mathrm{df}$ & MS \\
\hline Block & 2 & 0.09 & 2 & 0.56 & 2 & 0.59 \\
\hline Species & 2 & $15.7 * * \mathrm{z}$ & 2 & $10.7 * *$ & 2 & $5.70 * *$ \\
\hline Error a & 4 & 0.04 & 4 & 0.48 & 4 & 0.22 \\
\hline Harvest time & 16 & $8.73 * *$ & 16 & $4.37 * *$ & 11 & $5.14 * *$ \\
\hline Species $\times$ time & 32 & $0.98 * *$ & 32 & $0.73 * *$ & 22 & $0.47 * *$ \\
\hline Error b & 96 & 0.17 & 96 & 0.13 & 66 & 0.06 \\
\hline
\end{tabular}

$\mathrm{df}=$ Degrees of freedom, and MS = mean square error.

$* *$ Significant at the 0.01 level of probability. were placed with $5 \mathrm{ml}$ of methanol/water (1:9) in test tubes, mixed end-over-end for $1 \mathrm{~h}$, and then centrifuged for $5 \mathrm{~min}$ at $1,100 \times g$. The resulting supernatant was then passed through a $0.22-\mu \mathrm{m}$ filter. For the CD-ELISA, coating of plates with $100 \mu \mathrm{l}$ of the antibody suspension $(100 \mu \mathrm{g} / \mathrm{ml})$ per well was followed by drying overnight at $35^{\circ} \mathrm{C}$ and blocking of unbound sites with ovalbumin. The sample extract $(50 \mu \mathrm{l})$ was mixed with $50 \mu \mathrm{l}$ of DON conjugated to horseradish peroxidase (HRP; Sigma Chemical Co., St. Louis) solution $(2 \mu \mathrm{g} / \mathrm{ml})$, and this mixture was immediately added to each well. The amount of DON-HRP bound to the antibodies was determined by adding to each well $300 \mu$ l of the substrate $o$ phenylenediamine $(0.025 \mathrm{M}$ citric acid buffer containing $0.1 \%$ $\mathrm{H}_{2} \mathrm{O}_{2}$, pH 5.0, at a concentration of $0.4 \mathrm{mg} / \mathrm{ml}$ ), measuring the absorbance at $490 \mathrm{~nm}$ after $30 \mathrm{~min}$, and comparing the results with the inhibition produced by known DON concentrations as in Sinha and Savard (52).

$F B_{1}$. The $\mathrm{FB}_{1}$ ELISA (M. E. Savard and R. C. Sinha, personal communication) was performed as the DON ELISA described above, with minor modifications. Extraction of the maize was performed with five volumes of 1:1 acetonitrile/water. This solution was diluted to $15 \%$ acetonitrile before being added to the ELISA wells. Plates were layered with $3 \mu \mathrm{g}$ of antibody solution per $\mathrm{ml}$ at $125 \mu \mathrm{l} /$ well. The concentration of HRP conjugated to $\mathrm{FB}_{1}$ used was $0.125 \mu \mathrm{g} / \mathrm{ml}$, and that of the $o$-phenylenediamine (OPD) used as a color indicator of HRP concentration was $0.3 \mathrm{mg} / \mathrm{ml}$.

Antibody suspension (125 $\mu \mathrm{l})$ was dispensed into each well of a microtiter plate, and the plate was dried overnight at $50^{\circ} \mathrm{C}$. The next morning, ovalbumin $(300 \mu \mathrm{l}, 1 \%)$ was added to each well to block unbound sites. Sample extract $(50 \mu \mathrm{l})$ was mixed with an equal volume of $\mathrm{FB}_{1}-\mathrm{HRP}$, and the mixture was immediately added to each well. The free $\mathrm{FB}_{1}$ present in the samples inhibited the binding of $\mathrm{FB}_{1}$-HRP to the antibodies. The amount of $\mathrm{FB}_{1}-\mathrm{HRP}$ bound to the antibodies was determined by adding an OPD solution and recording the absorbance of the resulting solution at $490 \mathrm{~nm}$, after stopping the reaction at $30 \mathrm{~min}$ with $5 \mathrm{~N} \mathrm{HCl}(50 \mu \mathrm{l}$ per well). A mixture of equal volumes of $\mathrm{FB}_{1}$ solutions of known concentration and $\mathrm{FB}_{1}$-HRP was included in each assay to provide a standard curve correlating percent inhibition of $\mathrm{FB}_{1}$-HRP binding by $\mathrm{FB}_{1}$ to $\mathrm{FB}_{1}$ concentration in solution (52). All data points represent the average of two measurements.

In vivo growth rate measurements. The method described by Newell and Fallon (38) was used to measure fungal growth rates. In 1993, samples of maize silks were removed from $10 \mathrm{~F}$. gram-

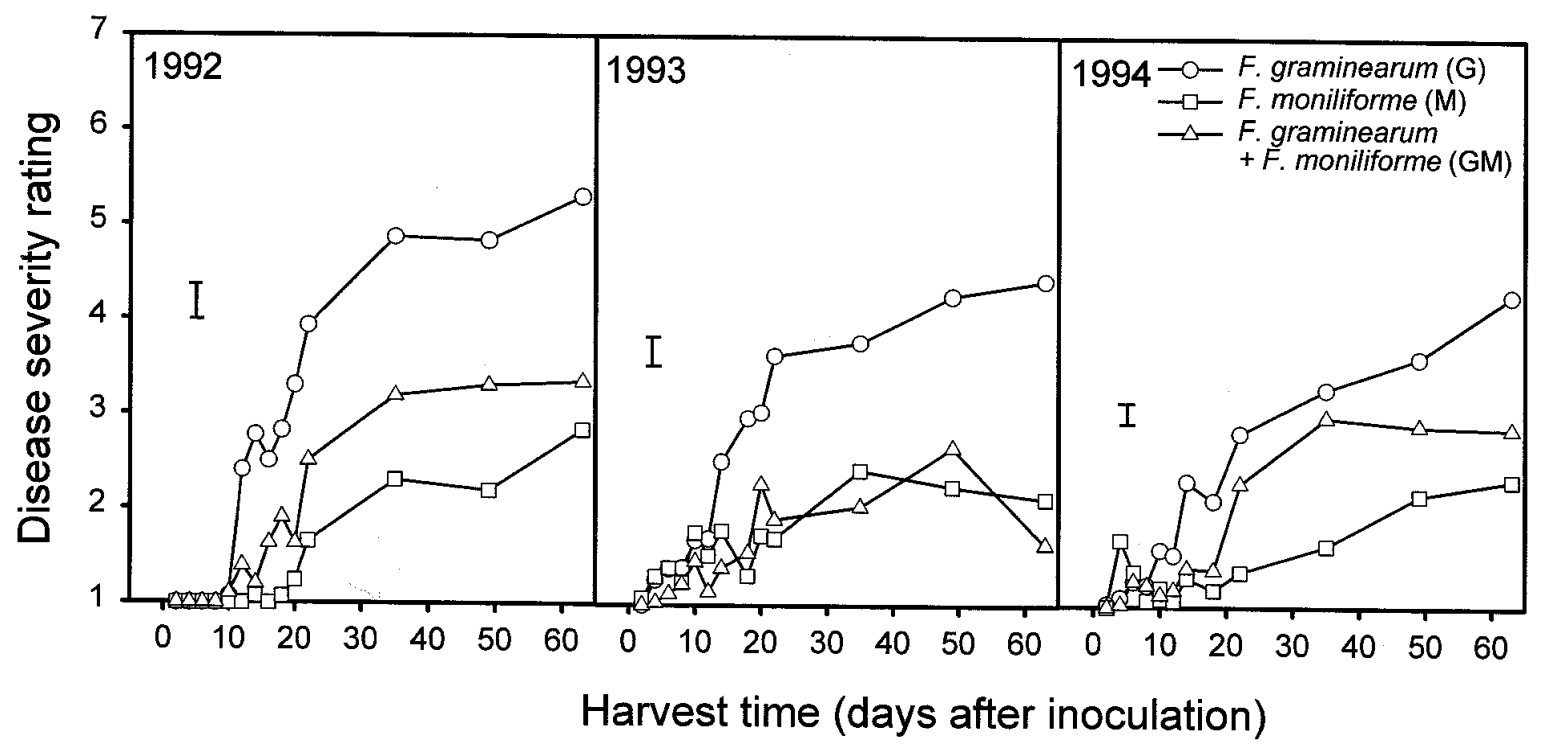

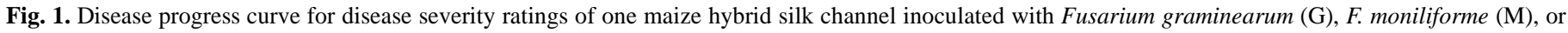

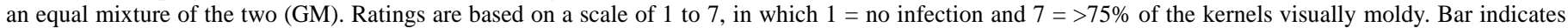
the standard error of the difference: 0.34 in 1992, 0.29 in 1993, and 0.20 in 1994. 
inearum- and F. moniliforme-inoculated plants 2 weeks postinoculation and placed into sterile plastic bags. These were immediately taken to the laboratory and approximately 1-g (wet weight) amounts of the fungal-silk material were placed in plastic scintillation vials containing sterile water. A total of $10 \mathrm{mmol}$ of $\mathrm{Na}$ acetate per liter (1-14C, $110 \mathrm{mCurie} / \mathrm{mmol}, \mathrm{ICN}$ Biomedicals, Inc.) was added to each of 10 vials; five of these had formaldehyde added to a final concentration of $2 \%$. Sets of 10 were incubated for $1 \mathrm{~h}$ at 24,26 , 28 , and $30^{\circ} \mathrm{C}$. After $1 \mathrm{~h}$, material from the vials was filtered on $0.45-\mu \mathrm{m}$ Millipore filters, rinsed with two portions of $10 \mathrm{ml}$ of water and $5 \mathrm{ml}$ of methanol, and transferred to a reflux flask, after which $15 \mathrm{ml}$ of methanol was added. Ergosterol was extracted by refluxing this solution, followed by saponification in methanol/KOH and ethanol, partitioning into pentane, drying down, and redissolving into methanol. Ergosterol concentrations were determined by HPLC with a UV detector at $282 \mathrm{~nm}$ after Miller et al. (31). Ergosterol (Sigma Chemical Co.) was recrystallized and was $>99 \%$ pure as determined by GC-MS. Standards ( $2.2 \mu \mathrm{g}$ injected) produced an average daily deviation of $\pm 1.5 \%$. As the ergosterol peak left the detector, it was collected in a scintillation vial and the radioactivity determined. Values were calculated as picometers of acetate incorporated per milligrams of fungal biomass per hour, subtracting the values for the killed cultures. Relative geometric standard deviations were $11 \%$ for the killed controls and $12 \%$ for the viable cultures. Fungal biomass was converted from ergosterol using the conversion factor of 200 (11).

Statistical analysis. For all dependent variables, residual error terms were generated and tested for normal distribution using the
Kolmogorov D statistic, and error mean squares were tested for homogeneity (SAS Institute, Cary, NC). Any data sets that violated these assumptions were log-transformed. Univariate analysis of variance (ANOVA) for a split-plot design was conducted to assess the significance of block, species, harvest time, and interaction effects on mean disease ratings, ergosterol concentrations, and DNA (mixture treatment only) and mycotoxin content using SAS (version 5, SAS Institute). Mean Fusarium spp. DNA recovery of the single inoculation treatments $(\mathrm{G}$ and $\mathrm{M})$ were derived from one block and separated using either Tukey's or KolmogorovSmirnov tests in SYSTAT (SPSS Inc., Chicago, IL). Pearson's correlation coefficients were generated to determine the relationship between symptoms and ergosterol concentration and the relationship between silk channel temperature and air temperature using SYSTAT (SPSS Inc.), and the $t$ test function of this program was used to compare the in vivo growth means. Area under the disease progress curve values (AUDPC) were calculated for each species within each block for disease severity, and ANOVA (and assumptions) was used as above to test the significance of block and species effects for AUDPC values (5). Means were then separated in SAS (SAS Institute) using a Fisher's least significant difference test.

\section{RESULTS}

Disease severity and ergosterol concentrations. Disease severity ratings were significantly $(P<0.01)$ affected by species treatment, harvest time, and species-harvest time interaction for all 3 years (Table 1). The $\mathrm{G}$ treatment always exhibited the greater

TABLE 2. Analysis of variance for ergosterol concentration $(\mu \mathrm{g} / \mathrm{g})$ in two tissues after inoculation of the silk channel with Fusarium graminearum, F. moniliforme, or a mixture of the two species in 1992, 1993, and 1994

\begin{tabular}{|c|c|c|c|c|c|c|c|c|c|c|c|c|}
\hline \multirow[b]{3}{*}{ Source } & \multicolumn{6}{|c|}{ Silk ergosterol } & \multicolumn{6}{|c|}{ Kernel ergosterol } \\
\hline & \multicolumn{2}{|c|}{1992} & \multicolumn{2}{|c|}{1993} & \multicolumn{2}{|c|}{1994} & \multicolumn{2}{|c|}{1992} & \multicolumn{2}{|c|}{1993} & \multicolumn{2}{|c|}{1994} \\
\hline & $\mathrm{df}^{\mathrm{y}}$ & $\mathrm{MS}^{\mathrm{y}}$ & $\mathrm{df}$ & MS & $\mathrm{df}$ & MS & $\mathrm{df}$ & MS & $\mathrm{df}$ & MS & $\mathrm{df}$ & MS \\
\hline Species & 2 & $292,913.7 * * z$ & 2 & $51.5^{*}$ & 2 & $8,091.3 * *$ & 2 & 96.2 & 2 & $1,633.8$ & 2 & $278.7 * *$ \\
\hline Error a & 4 & $31,705.6$ & 4 & 3.26 & 4 & 282.4 & 4 & 110.6 & 4 & 436.7 & 4 & 12.4 \\
\hline Harvest time & 8 & $116,654.6 * *$ & 6 & $36.6 * *$ & 6 & $5,210.6 * *$ & 10 & $290.0 *$ & 16 & $1,270.9 * *$ & 11 & $291.3 * *$ \\
\hline Species $\times$ time & 15 & $47,948.8 * *$ & 11 & $12.0 * *$ & 12 & $2,600.2 * *$ & 18 & $125.9 *$ & 32 & $530.2 * *$ & 22 & $103.2 * *$ \\
\hline
\end{tabular}

$\mathrm{df}=$ Degrees of freedom, and MS = mean square error.

$* z=$ Significant at the 0.05 level of probability, and $* *=$ significant at the 0.01 level of probability.

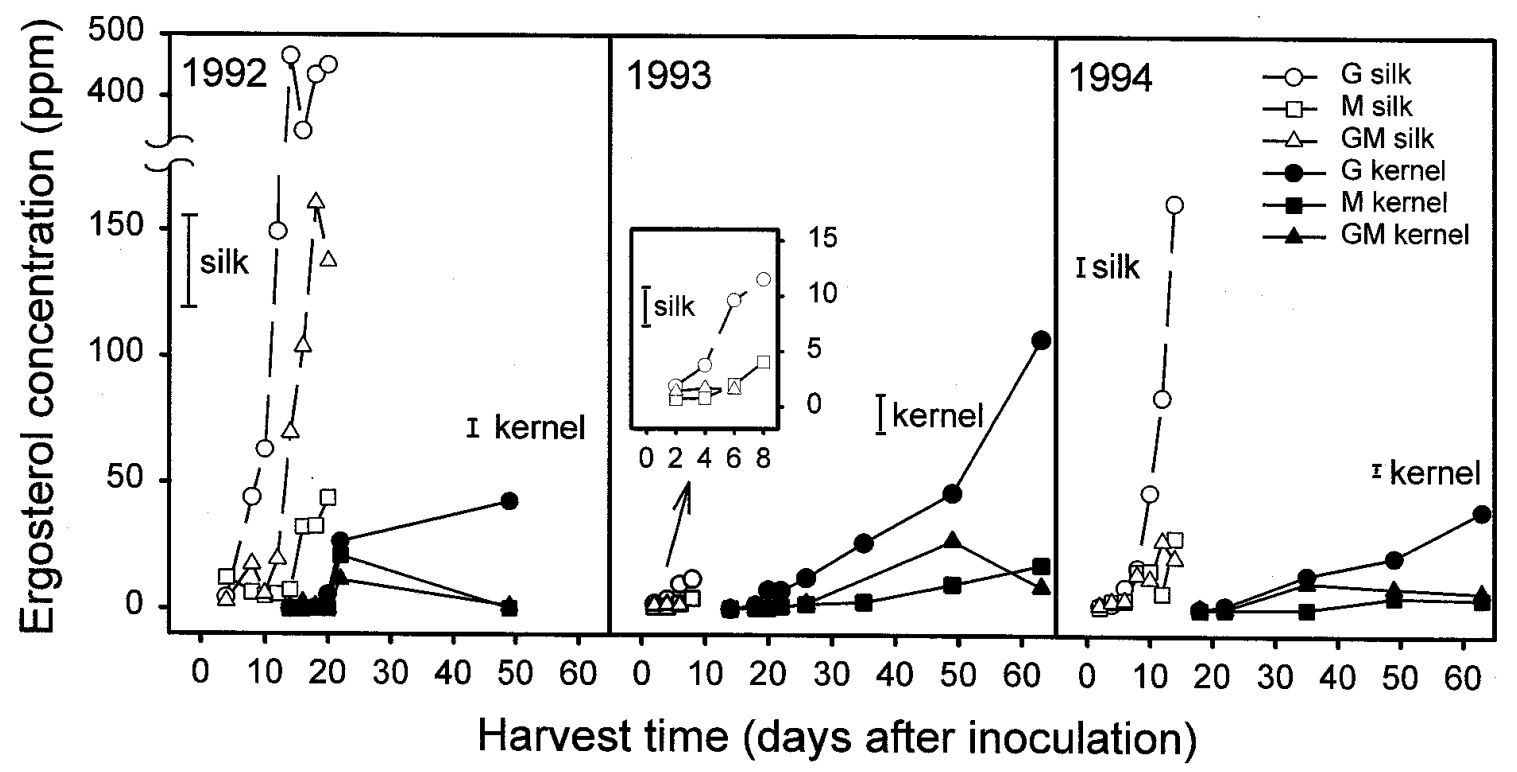

Fig. 2. Disease progress curve for ergosterol of one maize hybrid silk channel inoculated with Fusarium graminearum (G), F. moniliforme (M), or an equal mixture of the two (GM). Bar indicates the standard error of the difference: 33.26 (1992 silk), 4.94 (1992 kernel), 1.65 (1993 silk), 13.14 (1993 kernel), 15.81 (1994 silk), and 2.22 (1994 kernel). 
disease severity rating, followed by the GM treatment (Fig. 1). The $M$ treatment usually exhibited the lowest disease severity ratings throughout the experiment. On average, the greatest disease severity was in 1992. Sterile water control treatments had no symptoms, thus indicating little background infection.

For 3 years, species, harvest time, and the species-harvest time interaction were significant for ergosterol levels in both kernel and silk tissues (except for nonsignificant species effects for kernel ergosterol in 1992 and 1993) (Table 2). The trend seen with the disease severity data (highest levels in G, followed by GM and then M) was also seen in the ergosterol data (Fig. 2). Although the trend remained the same over the years, the absolute levels of ergosterol recovered changed, as did the levels in the two different tissues. In 1992 and 1994, the highest amounts of ergosterol were

TABLE 3. Pearson's correlation between disease severity and ergosterol levels in kernels of maize after Fusarium spp. inoculation

\begin{tabular}{llll}
\hline Year & Treatment $^{\mathrm{y}}$ & \multicolumn{1}{c}{$r$} & $n$ \\
\hline 1992 & $\mathrm{G}$ & $0.897^{* * \mathrm{z}}$ & 12 \\
& $\mathrm{M}$ & 0.388 & 13 \\
& $\mathrm{GM}$ & $0.737^{* *}$ & 14 \\
1993 & $\mathrm{G}$ & $0.647^{* *}$ & 21 \\
& $\mathrm{M}$ & $0.552^{*}$ & 20 \\
& $\mathrm{GM}$ & $0.532^{*}$ & 21 \\
1994 & $\mathrm{G}$ & $0.834^{* *}$ & 15 \\
& $\mathrm{M}$ & $0.567^{*}$ & 13 \\
& $\mathrm{GM}$ & $0.841^{* *}$ & 13 \\
\hline
\end{tabular}

$\mathrm{G}=F$. graminearum, $\mathrm{M}=F$. moniliforme, and $\mathrm{GM}=F$. graminearum plus F. moniliforme.

$* \mathrm{z}=$ Significant at the 0.05 level of probability, and $* *=$ significant at the 0.01 level of probability. recovered from the silk tissue, whereas, in 1993, the highest amounts were found in the kernels (Fig. 2). Overall, kernels inoculated with $F$. moniliforme contained significantly less ergosterol compared with $F$. graminearum. Kernel ergosterol was positively correlated to disease ratings (Table 3 ) for all years, except for $M$ in 1992. Minimal quantities of ergosterol were found in a few samples of the sterile water control, confirming little to no background infection.

Species effects on AUDPC values were significant in all years for disease severity (Table 4). In all years, the highest AUDPC values were found in the $\mathrm{G}$ treatment. For only 1 year, disease severity in 1994, was there a significant difference between AUDPC values for all three treatments.

DNA. DNA analysis allowed us to identify and quantify fungal species that were present in kernels at the time of sampling. The total DNA from fungal species of the Fusarium or closely related

TABLE 4. Mean area under the disease progress curve values (\% days) for disease severity for a maize hybrids silk channel inoculated with Fusarium graminearum, F. moniliforme, or a mix of the two species in 1992, 1993, and 1994

\begin{tabular}{lccc}
\hline & \multicolumn{3}{c}{ Disease severity $^{\mathrm{z}}$} \\
\cline { 2 - 4 } Treatment $^{\mathrm{y}}$ & 1992 & 1993 & 1994 \\
\hline $\mathrm{G}$ & $255.7 \mathrm{a}$ & $206.1 \mathrm{a}$ & $179.4 \mathrm{a}$ \\
$\mathrm{M}$ & $114.7 \mathrm{~b}$ & $123.4 \mathrm{~b}$ & $102.2 \mathrm{c}$ \\
$\mathrm{GM}$ & $157.1 \mathrm{~b}$ & $118.8 \mathrm{~b}$ & $143.5 \mathrm{~b}$ \\
\hline
\end{tabular}

Iłoculation treatments: $\mathrm{G}=F$. graminearum, $\mathrm{M}=F$. moniliforme, and $\mathrm{GM}=$ $F$. graminearum plus $F$. moniliforme.

Means followed by the same letter within a column for a given year and variable are not significantly different at the 0.05 probability level based on Fisher's (protected) least significant difference test.

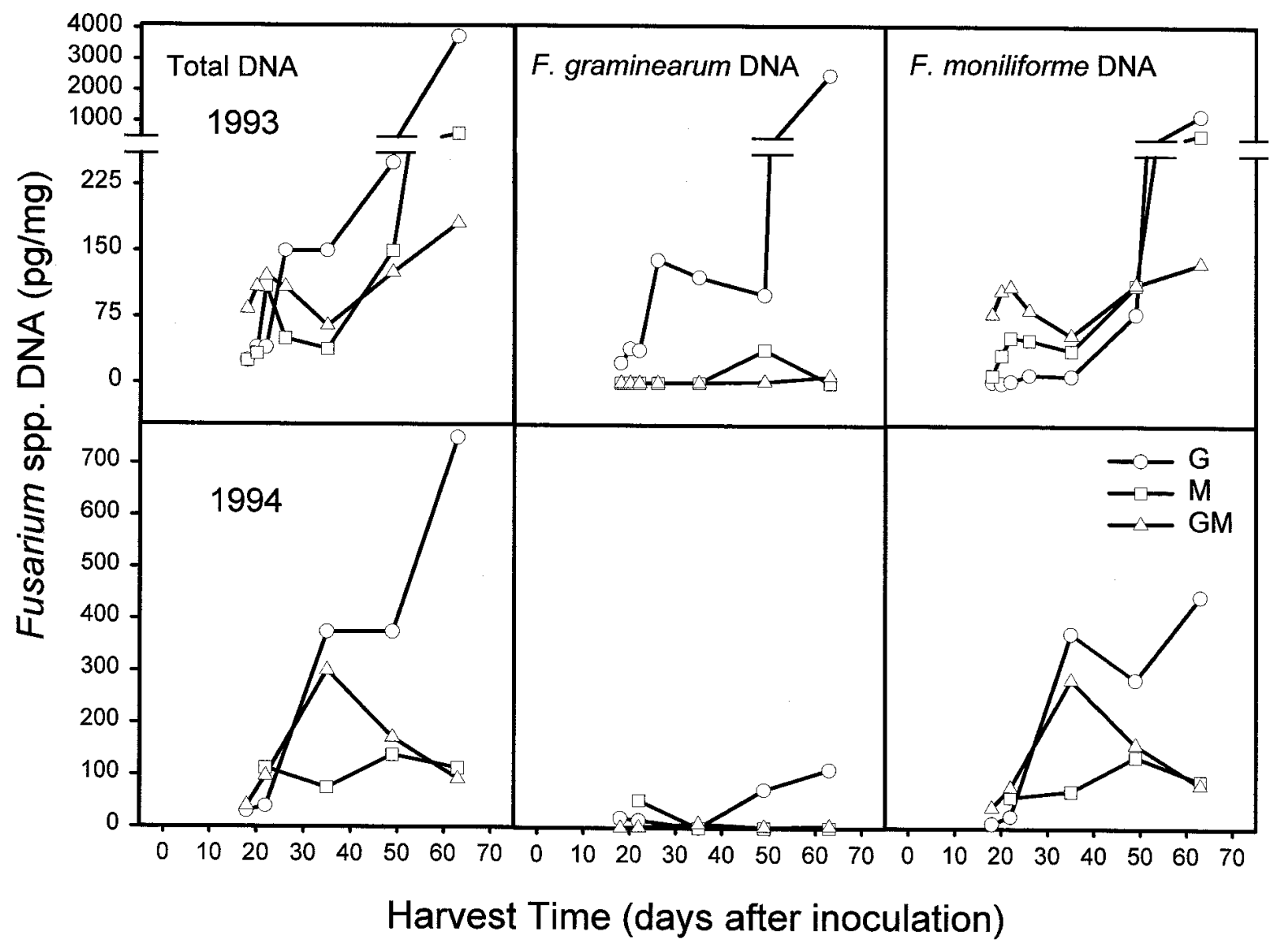

Fig. 3. Fusarium graminearum and F. moniliforme DNA recovered from the kernels of maize ears inoculated with $F$. graminearum (G), F. moniliforme (M), or an equal mixture of the two (GM) for 2 years, 1993 (top) and 1994 (bottom). Points in the G and M treatments represent one block only. The split-plot analysis of variance was then used to compare recovery of the two species from one treatment (GM), and a significant difference between species was found each year. The standard error of the difference for GM was 33.56 in 1993 and 74.49 in 1994. 
genera was detected and identified as originating either from $F$. graminearum, F. moniliforme, or other species (Fig. 3). Fungal species not closely related to the Fusarium genus were not detected by the DNA assay, but were detected by the ergosterol assay.

DNA data is only presented for 1993 and 1994, because the 1992 sample DNA had degraded by the time of analysis. In 1993, the high amount of fungal biomass detected close to maturity in kernels of the $G$ treatment by ergosterol and DNA analyses was due not only to the $F$. graminearum inoculum but also to the presence of $F$. moniliforme that had become established on the plants. In contrast, the $\mathrm{M}$ treatment contained no detectable $F$. graminearum DNA by the end of the experiment (Table 5). In 1994, levels of $F$. graminearum DNA were relatively low, even in the G treatment. By 63 days postinoculation, significantly more $F$. monil- iforme than $F$. graminearum DNA was recovered from the G treatment and, in 1993, no significant differences could be found between the two species, even though only $F$. graminearum was inoculated for this treatment (Table 5). The split-plot ANOVA revealed that, within the GM treatment, significantly more $F$. moniliforme DNA than $F$. graminearum DNA was recovered in both years. In 1994, the amount of F. moniliforme DNA at day 35 had a high variance and is not significantly different from the mean at day 49 (Fig. 3). Other fungal species were also detected in both years; however, their biomass varied within and between fungal treatments. In water-inoculated controls (data not shown), the fungal DNA detected was mainly from species other than $F$. graminearum and $F$. moniliforme (in 1994, a variable and small amount of $F$. moniliforme DNA was found).

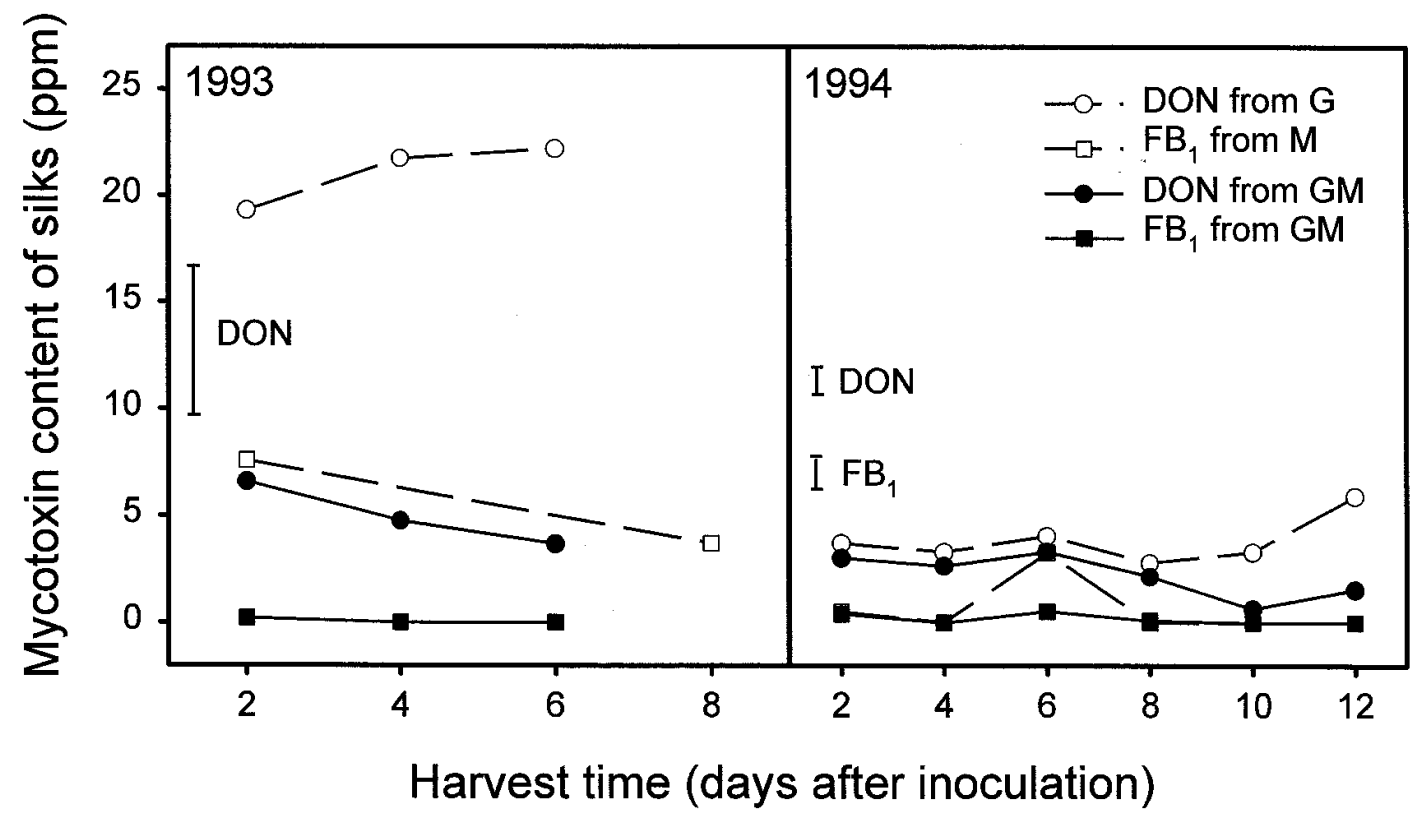

Fig. 4. Concentrations of the mycotoxins deoxynivalenol (DON) and fumonisin $\mathrm{B}_{1}\left(\mathrm{FB}_{1}\right)$ in the silks of maize ears inoculated with Fusarium graminearum (G), F. moniliforme (M), or an equal mixture of the two (GM). Bar indicates the standard error of the difference: 6.79 for DON $1993,0.00$ for FB 1993 , 1.12 for DON 1994, and 1.29 for $\mathrm{FB}_{1} 1994$.

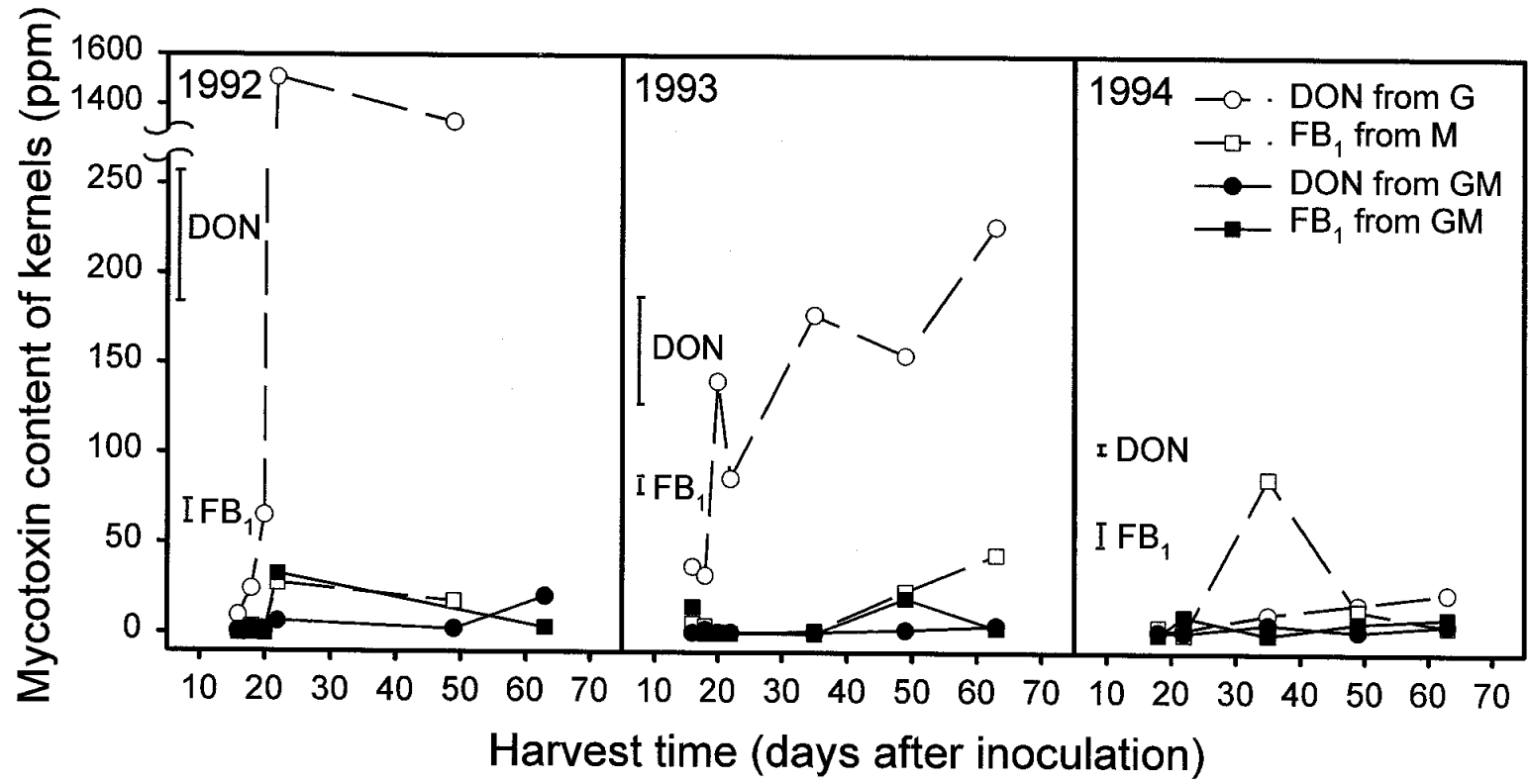

Fig. 5. Concentrations of the mycotoxins deoxynivalenol (DON) and fumonisin $\mathrm{B}_{1}\left(\mathrm{FB}_{1}\right)$ in the kernels of maize ears inoculated with Fusarium graminearum (G), F. moniliforme (M), or an equal mixture of the two (GM). Bar indicates the standard error of the difference: 73.82 for DON 1992 , 10.19 for $\mathrm{FB}_{1} 1992$, 57.31 for DON 1993, 7.69 for $\mathrm{FB}_{1}$ 1993, 4.33 for DON 1994, and 10.48 for $\mathrm{FB}_{1} 1994$. 
Mycotoxins. With the exception of silk in 1992 and some later silk dates in which insufficient tissue was available, mycotoxin analysis was completed for all years in kernels and silks. Silk mycotoxin levels were not high ( $<5$ parts per million [ppm]), except for DON in the F. graminearum-inoculated ears in 1993 (Fig. 4). Figure 4 demonstrates that, in both years as time progressed, DON and $\mathrm{FB}_{1}$ levels remained relatively stable. As with $\mathrm{DON}$, silk $\mathrm{FB}_{1}$ levels in the $M$ treatment were higher in 1993 than in 1994. Thus, the trend of higher levels seen in the silk ergosterol in 1994 versus 1993 was not reflected in the toxin concentrations. Partial data from the DNA analysis of silk in 1994 (data not shown) indicated that most of the fungal biomass in the late sampling dates in the $\mathrm{G}$ treatment was not $F$. graminearum, but rather $F$. moniliforme and other fungal species. Therefore, a relationship between DON levels in this year and treatment and ergosterol levels was not expected. With simultaneous inoculation (GM), DON levels were lower than levels found in the $G$ treatment and appeared to decrease with time, agreeing with the DNA results. $\mathrm{FB}_{1}$ levels in GM remained low throughout the time course and, in some cases, were significantly lower than $\mathrm{FB}_{1}$ levels in the $\mathrm{M}$ treatment (Fig. 4).

TABLE 5. Amount of Fusarium spp. DNA recovered 63 days postinoculation from the single species treatments ${ }^{\mathrm{y}}$

\begin{tabular}{lccc}
\hline Species & Treatment $^{\mathrm{z}}$ & 1993 & 1994 \\
\hline F. graminearum & $\mathrm{G}$ & $2,512.5 \mathrm{a}$ & $112.5 \mathrm{~b}$ \\
F. graminearum & $\mathrm{M}$ & $0 \mathrm{c}$ & $0 \mathrm{c}$ \\
F. moniliforme & $\mathrm{G}$ & $1,237.5 \mathrm{a}$ & $446.3 \mathrm{a}$ \\
F. moniliforme & $\mathrm{M}$ & $625.0 \mathrm{~b}$ & $89.0 \mathrm{~b}$ \\
\hline
\end{tabular}

DNA recovered $(\mathrm{pg} / \mathrm{mg})$ for each year. Means followed by the same letter are not significantly different $(P>0.05)$ in a Kolmogorov-Smirnov (1993) or Tukey's (1994) test.

Ihocoulation treatments: $\mathrm{G}=F$. graminearum and $\mathrm{M}=F$. moniliforme.
In the kernels, very high concentrations of DON were found in the 1992 and $1993 \mathrm{G}$ treatments (Fig. 5) and both of these years had high disease severity. DNA data in 1994 showed more $F$. moniliforme than F. graminearum in the $\mathrm{G}$ treatment; therefore, the lower DON levels were expected. When both species were inoculated simultaneously, DON levels were less than $20 \mathrm{ppm}$ in 1992 and almost zero in 1993 and 1994 . FB 1 levels generally remained the same between the $F$. moniliforme alone and the mixture treatment.

In vivo growth rate. Data on the growth rates of the strains of $F$. graminearum and $F$. moniliforme on silk tissue collected in the field in this study are shown in Table 6. Growth differences between the two species were observed at the various tested temperatures. Although there was no significant difference in growth rate at $28^{\circ} \mathrm{C}, F$. moniliforme grew significantly faster than $F$. graminearum at the remaining temperatures (Table 6). This trend seemed to be stronger at the extremes of the temperature regime, with growth rates of $F$. moniliforme roughly doubling those of $F$. graminearum at the lowest $\left(24^{\circ} \mathrm{C}\right)$ and highest $\left(30^{\circ} \mathrm{C}\right)$ temperatures.

TABLE 6. In vivo growth of two species of Fusarium cultured under four temperature regimes

\begin{tabular}{lcc}
\hline & \multicolumn{2}{c}{ Mean fungal growth rate $^{\mathrm{y}}$} \\
\cline { 2 - 3 } Temperature & F. moniliforme & F. graminearum \\
\hline $24^{\circ} \mathrm{C}$ & 10.6 & $4.5^{* * \mathrm{z}}$ \\
$26^{\circ} \mathrm{C}$ & 15.0 & $19.3^{*}$ \\
$28^{\circ} \mathrm{C}$ & 20.0 & 20.5 \\
$30^{\circ} \mathrm{C}$ & 22.6 & $11.6^{* *}$ \\
\hline
\end{tabular}

Mean growth rate (pm of acetate/mg of fungal biomass/h) for F. moniliforme versus $F$. graminearum is compared at each temperature.

$* \mathrm{z}=$ Significant at the 0.05 level of probability, and $* *=$ significant at the 0.01 level of probability as determined by a $t$ test.

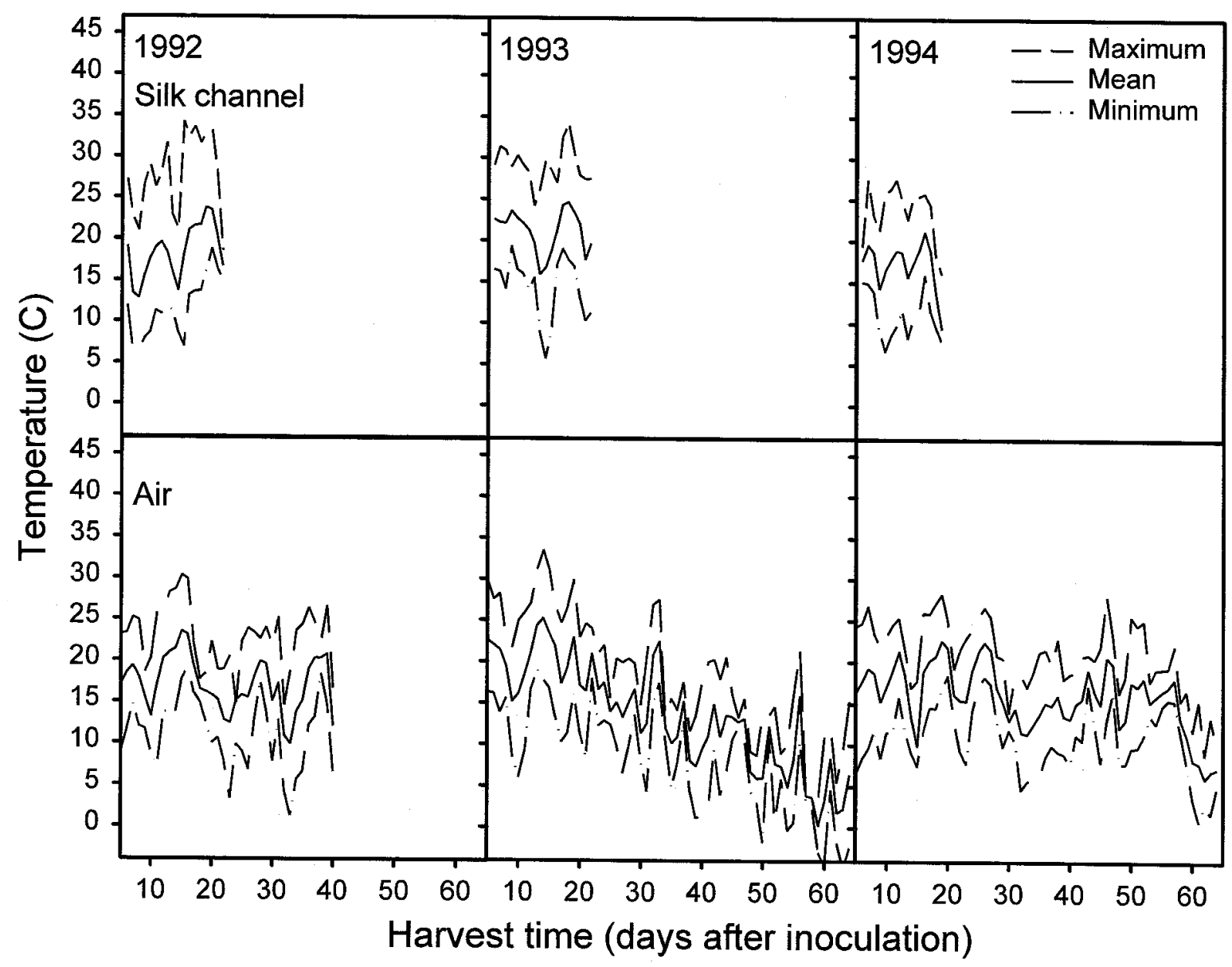

Fig. 6. The maximum, mean, and minimum temperature $\left({ }^{\circ} \mathrm{C}\right)$ of the silk channel (top) and of the air (bottom) as measured by a thermocouple, from 1992 to 1994. 
Environmental conditions. The temperature of the silk channel was similar across the 3 years (Fig. 6). However, the maximum, mean, and minimum temperatures were generally warmer in 1993 than in 1992 and 1994 for the first 8 days postinoculation. The mean air temperature measured in the plots (Fig. 6) was highly correlated (Pearson's $r>0.96, P<0.0005$ ) to the mean silk channel temperature during the 3 years, and it is assumed that air temperature is the largest determinant of ear temperature. Like silk channel temperature, air temperature was generally the warmest in 1993 for the earlier days postinoculation. The mean air temperature in 1993 decreased more rapidly than in other years and, after day 35, was always lower than the corresponding days in 1994 (Fig. 6).

The highest amount of moisture in the silk was recorded in 1992, followed by 1993 and then 1994 (Fig. 7). In 1993, the silk tissue had completely senesced by 8 days postinoculation. Kernel tissue contained the most moisture in 1992, followed by 1994 and then 1993 (Fig. 7).

\section{DISCUSSION}

Fungal biomass, as ergosterol, for all treatments remained in the silk tissue in 1992 and 1994, whereas, in 1993, the ergosterol analysis revealed that the fungi quickly invaded the kernels. In this year, silk tissue had almost completely senesced by the eighth day after inoculation. The $\mathrm{G}$ treatment consistently rated the highest on the disease severity scale, because it consistently produced the most fungal biomass. However, the ergosterol method identifies total fungal biomass (that is, it is not species specific). Although biomass may be the best predictor of disease ratings, the DNA analysis demonstrated that this biomass was not always produced by the expected Fusarium sp. In the GM treatment in both 1993 and 1994, F. moniliforme was the predominant species. The main question posed by these results is how does $F$. moniliforme have an advantage over $F$. graminearum and, as a corollary, why in 1994 was there relatively more $F$. moniliforme recovered from the G treatment?

In Ontario and elsewhere, epidemiological and field studies report an association between drier and warmer growing conditions with $F$. moniliforme and wetter conditions with intermediate temperatures with $F$. graminearum $(29,30,54,59)$. This observation is supported by the current studies. The in vivo growth rate data show clearly that temperature conditions strongly affect the infection. In the 2 years when $F$. moniliforme out-competed $F$. graminearum when inoculated as a mixture, the likely major factor is the impact of daytime temperatures. This impact is complex in that, if the conditions are marginal for $F$. graminearum to grow and infect the plant, F. moniliforme colonization after inoculation may occur because of its ability to grow over a wider range of conditions.

It has been suggested that $F$. graminearum predisposes the ear to $F$. moniliforme infection (30). This may address the question of where the $F$. moniliforme infection originally came from in the $\mathrm{G}$ treatment in 1994. It is thought that $F$. moniliforme is systemic in maize plants $(2,9,34)$ and ubiquitous in nature $(28,35)$. High rates of $F$. moniliforme recovery from $F$. graminearum-inoculated maize have also been observed in other experiments (49; A. W. Schaafsma, unpublished data). If $F$. moniliforme is ubiquitous, it is not obviously pathogenic every year $(2,21,24)$.

If $F$. graminearum predisposes the plant to $F$. moniliforme, then there is likely an environmental effect, because $F$. moniliforme was isolated from $\mathrm{G}$ treatment plots at a greater level in 1994 than in 1993. Our results and previously completed laboratory studies revealed that $F$. moniliforme has an enhanced ability not only to grow over a broader range of temperatures and water activities, but also to germinate. Conditions at the environmental periphery (the maximum and minimum values at which the fungi can still respond) may present $F$. moniliforme with an opportunity to out-compete $F$. graminearum. For example, the minimum water activity $\left(a_{\mathrm{w}}\right)$ and temperature needed by $F$. moniliforme for growth is generally reported to be 0.86 to $0.90 a_{\mathrm{w}}$ and $4^{\circ} \mathrm{C}$, respectively $(26,63)$, whereas the same conditions reported for $F$. graminearum are $0.935 a_{\mathrm{w}}$ and $10^{\circ} \mathrm{C}(6)$. This trend is even more evident in the minima needed for spore germination. $F$. graminearum is reported to need a minimum $a_{\mathrm{w}}$ of 0.94 to 0.95 at $25^{\circ} \mathrm{C}$ to germinate (53), whereas, at approximately the same temperature, the ascospores of $F$. moniliforme are reported to be able to germinate down to $0.88 a_{\mathrm{w}}$ (27).

Growing conditions in 1994 could have theoretically favored $F$. moniliforme. In 1994, the minimum and mean silk channel temperature was lower than in 1993, especially in the first days after inoculation (days 1 to 6 ). The mean temperatures during this period (1993 versus 1994) ranged from 20 to $25^{\circ} \mathrm{C}$ versus 15 to $20^{\circ} \mathrm{C}$, and the minimum temperatures ranged from 15 to $20^{\circ} \mathrm{C}$ versus 7 to $15^{\circ} \mathrm{C}$, respectively (Fig. 6). Also, the silk tissue was drier in 1994 than in 1993 during this period (Fig. 7). The temperature and water conditions in 1994 may, therefore, have been too low for F. graminearum to germinate and grow (in both the G and GM treatments) to a critical level, which may have left the ear open for $F$. moniliforme colonization.

From the results presented here, it can be stated that $F$. moniliforme has at least one competitive advantage over $F$. graminearum: a broader response to temperature that confers direct and indirect benefits. What remains unclear is whether this is the only factor involved or whether there are others. It was thought that the dif-

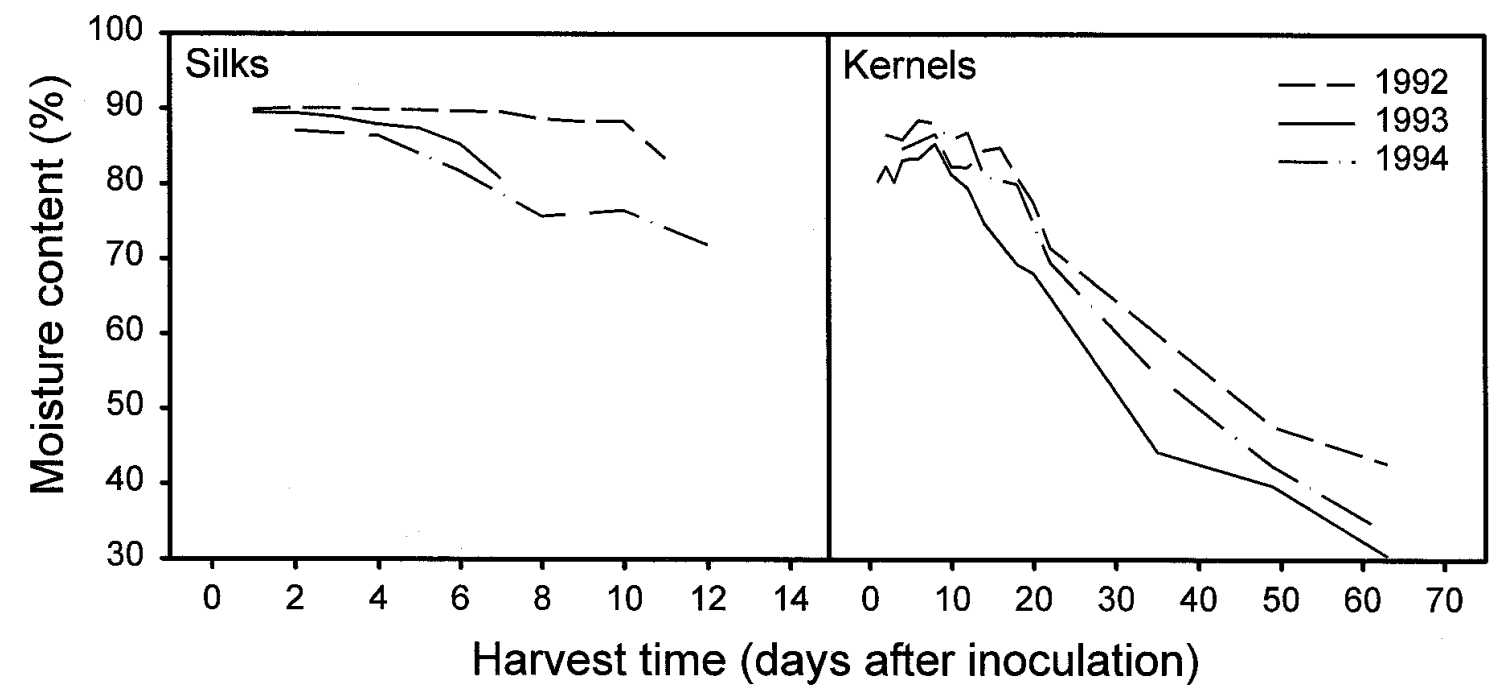

Fig. 7. The percent moisture content of silk and kernel tissue from 1992 to 1994. 
ferent mycotoxins produced by the two species may be a competitive factor (chemical antagonism), because it has been suggested that the production of secondary fungal metabolites are ecologically significant and confer increased fitness to the producing organism $(3,4,41)$. Changes in mycotoxin levels in response to fungal interactions have been shown with aflatoxin in A. flavus (18) and with zearalenone and T-2 in Fusarium spp. $(7,44)$.

If $F$. moniliforme uses $\mathrm{FB}_{1}$ as a competitive advantage over $F$. graminearum, then one would expect higher concentrations of this toxin in the GM and G (1994) treatments than in the M treatment. This was not observed in either the silk or kernel tissue. Also, no negative correlation was found between $\mathrm{FB}_{1}$ concentration and $F$. graminearum DNA levels. As opposed to the other measured variables (disease severity, ergosterol, and DNA), interaction between the two fungal species did not seem to directly influence the mycotoxin production or accumulation. Therefore, the data does not support the hypothesis that $F$. moniliforme gains a competitive advantage over $F$. graminearum via $\mathrm{FB}_{1}$. Both species produce various toxins, the bioactivity of which has not been thoroughly investigated; therefore, the idea of chemical antagonism between $F$. moniliforme and $F$. graminearum cannot be dismissed.

The results of this study suggest that, for the purpose of breeding maize for resistance to $F$. graminearum and $F$. moniliforme, a "cocktail" mixture of the two species would not be appropriate. The breeder may not know for which species he or she was selecting unless further analyses were conducted, special attention was paid to the environmental conditions, or both. Improved selection can be made by inoculating each species individually, thus avoiding the complicated competitive interactions.

\section{CONCLUSIONS}

The experimental data demonstrated that $F$. moniliforme can outcompete $F$. graminearum when the temperature conditions are not favorable for the latter species. This implies that the outcome of the fungal competition will change as growing conditions change from season to season (i.e., the results demonstrated here may not be consistent between years and locations). However, there is evidence suggesting that $F$. moniliforme is a highly competitive colonizer of maize that can successfully compete against fungi in many genera $(48,61,66)$. F. moniliforme may, therefore, possess a stable competitive advantage over $F$. graminearum as well as other fungal species.

\section{ACKNOWLEDGMENTS}

ECORC contribution no. 991408. This research was supported, in part, by Pioneer Hi-Bred International, the Ontario Corn Producers' Association, and the Ontario Pork Producers Marketing Board. We thank T. Woldemariam, Y. Chen, K. O'Flaherty, A. Koul, M. Ewen, M. Matthews, A. Hierlihy, C. Séguin, S. Buffam, and R. Eedy for their technical support.

\section{LITERATURE CITED}

1. Attwater, W. A., and Busch, L. V. 1983. Role of the sap beetle Glischrochilus quadrisignatus in the epidemiology of gibberella corn ear rot. Can. J. Plant Pathol. 5:158-163.

2. Bacon, C. W., and Williamson, J. W. 1992. Interactions of Fusarium moniliforme, its metabolites and bacteria in corn. Mycopathologia 117: 65-71.

3. Brian, P. W. 1957. The ecological significance of antibiotic production. Pages 168-188 in: Microbial Ecology. R. E. O. Williams and C. C. Spicer, eds. Cambridge University Press, Cambridge.

4. Bruehl, G. W., Cunfer, B., and Toivainen, M. 1972. Influence of water potential on growth, antibiotic production, and survival of Cephalosporum gramineum. Can. J. Plant Sci. 52:417-423.

5. Campbell, C. L., and Madden, L. V. 1990. Introduction to Plant Disease Epidemiology. John Wiley \& Sons, New York.

6. Cook, R. J., and Christen, A. A. 1976. Growth of cereal root-rot fungi as affected by temperature-water potential interactions. Phytopathology 66: 193-197.
7. Cuero, R., Smith, J. E., and Lacey, J. 1988. Mycotoxin formation by Aspergillus flavus and Fusarium graminearum in irradiated maize grains in the presence of other fungi. J. Food Prot. 51:452-456.

8. Enerson, P. M., and Hunter, R. B. 1980. A technique for screening maize (Zea mays L.) for resistance to ear mold incited by Gibberella zeae (Schw.) Petch. Can. J. Plant Sci. 60:1123-1128.

9. Foley, D. C. 1962. Systemic infection of corn by Fusarium moniliforme. Phytopathology 52:870-872.

10. Gelderblom, W. C. A., Jaskiewicz, K., Marasas, W. F. O., Thiel, P. G., Horak, R. M., Vleggaar, R., and Kriek, P. J. 1988. Fumonisins-novel mycotoxins with cancer-promoting activity produced by Fusarium moniliforme. Appl. Environ. Microbiol. 54:1806-1811.

11. Gessner, M. O., and Newell, S Y. 1997. Bulk quantitative methods for the examination of eukaryotic organoosmotrophs in plant litter. Pages 295-308 in: Manual of Environmental Microbiology. C. J. Hurst, G. R. Knudsen, M. J. McInerney, L. D. Stetzenbach, and M. V. Walter, eds. ASM Press, Washington, DC.

12. Gilliland, G., Perrin, S., Blanchard, K., and Bunn, H. F. 1990. Analysis of cytokine mRNA and DNA: Detection and quantitation by competitive polymerase chain reaction. Proc. Natl. Acad. Sci. U.S.A. 87:2725-2729.

13. Goodwin, P. H., and Nassuth, A. 1993. Detection and characterization of plant pathogens. Pages 303-319 in: Methods in Plant Molecular Biology and Biotechnology. B. R. Glick and J. E. Thompson, eds. CRC Press, Boca Raton, FL.

14. Harrison, L. R., Colvin, B. N., Greene, J. T., Newman, L. E., and Cole, R. J. 1990. Pulmonary edema and hydrothorax in swine produced by fumonisin B1, a toxic metabolite of Fusarium moniliforme. J. Vet. Diagn. Invest. 2:217-221.

15. Headrick, J. M., and Pataky, J. K. 1991. Maternal influence on the resistance of sweet corn lines to kernel infection by Fusarium moniliforme. Phytopathology 81:268-274.

16. Headrick, J. M., Pataky, J. K., and Juvik, J. A. 1990. Relationships among carbohydrate content of kernels, condition of silks after pollination, and the response of sweet corn inbred lines to infection of kernels by $F u$ sarium moniliforme. Phytopathology 80:487-494.

17. Hesseltine, C. W., and Bothast, R. J. 1977. Mold development in ears of corn from tasseling to harvest. Mycologia 69:328-340.

18. Horn, B. W., and Wicklow, D. T. 1983. Factors influencing the inhibition of aflatoxin production in corn by Aspergillus niger. Can. J. Microbiol. 29:1087-1091.

19. International Agency for Research on Cancer (IARC). 1993. Monograph 56: Some naturally occurring substances: Some food items and constituents, heterocyclic amines and mycotoxins. IARC, Lyon, France.

20. Kellerman, T. S., Marasas, W. F. O., Thiel, P. G., Gelderblom, W. C. A., Cawood, M., and Coetzer, J. A. W. 1990. Leukoencephalomalacia in two horses induced by oral dosing of fumonisin $\mathrm{B}_{1}$. Onderstepoort J. Vet. Res. 57:269-275.

21. King, S. B., and Scott, G. E. 1981. Genotypic differences in maize to kernel infection by Fusarium moniliforme. Phytopathology 71:1245-1247.

22. Koehler, B. 1942. Natural mode of entrance of fungi into corn ears and some symptoms that indicate infection. J. Agric. Res. 64:421-442.

23. Koehler, B. 1959. Corn ear rots in Illinois. Ill. Agric. Exp. Stn. Bull. 639.

24. Kommedahl, T., Windels, C. E., and Stucker, R. E. 1979. Occurrence of Fusarium species in roots and stalks of symptomless corn plants during the growing season. Phytopathology 69:961-966.

25. Marasas, W. F. O., Kriek, N. P. J., Wiggins, V. M., Steyn, P. S., Towers, D. K., and Hastie, T. J. 1979. Incidence, geographical distribution, and toxigenicity of Fusarium species in South African corn. Phytopathology 69:1181-1185.

26. Marín, S., Sanchis, V., and Magan, N. 1995. Water activity, temperature, and $\mathrm{pH}$ effects on growth of Fusarium moniliforme and Fusarium proliferatum isolates from maize. Can. J. Microbiol. 41:1063-1070.

27. Marín, S., Sanchis, V., Teixido, R., Saenz, A. J., Ramos, I., and Magan, N. 1996. Water and temperature relations and microconidial germination of Fusarium moniliforme and Fusarium proliferatum from maize. Can. J. Microbiol. 42:1045-1050.

28. Miller, J. D. 1994. Epidemiology of Fusarium ear diseases of cereals. Pages 19-35 in: Mycotoxins in Grain: Compounds Other than Aflatoxin. J. D. Miller and H. L. Trenholm, eds. The American Phytopathological Society, St. Paul, MN.

29. Miller, J. D., Culley, J., Fraser, K., Hubbard, S., Meloche, F., Ouellet, T., Seaman, L., Seifert, K. A., Turkington, K., and Voldeng, H. 1998. Effect of tillage practice on Fusarium head blight of wheat. Can. J. Plant Pathol. 20:95-103.

30. Miller, J. D., Savard, M. E., Schaafsma, A. W., Seifert, K. A., and Reid, L. M.. 1995. Mycotoxin production by Fusarium moniliforme and Fusarium proliferatum from Ontario and occurrence of fumonisin in the 1993 corn crop. Can. J. Plant Pathol. 17:233-239.

31. Miller, J. D., Young, J. C., and Trenholm, H. L. 1983. Fusarium toxins in 
field corn. I. Time course of fungal growth and production of deoxynivalenol and other mycotoxins. Can. J. Bot. 61:3080-3087.

32. Möeller, E. M., Bahnweg, G., Sandermann, H., and Geiger, H. H. 1992. A simple and efficient protocol for isolation of high molecular weight DNA from filamentous fungi, fruit bodies, and infected plant tissues. Nucleic Acids Res. 20:6115-6116.

33. Moukhamedov, R., Hu, X., Nazar, R. N., and Robb, J. 1994. Use of polymerase chain reaction-amplified ribosomal intergenic sequences for the diagnosis of Verticillium tricorpus. Phytopathology 84:255-259.

34. Munkvold, G. P., McGee, D. C., and Carlton, W. M. 1997. Importance of different pathways for maize kernel infection by Fusarium moniliforme. Phytopathology 87:209-217.

35. Nelson, P. E. 1992. Taxonomy and biology of Fusarium moniliforme. Mycopathologia 117:29-36.

36. Nes, W. R. 1974. Role of sterols in membranes. Lipids 9:596.

37. Neubauer, A., Neubauer, B., and Liu, E. 1990. Polymerase chain reaction based assay to detect allelic loss in human DNA: Loss of beta-interferon gene in chronic myelogeneous leukemia. Nucleic Acids Res. 18:993-998.

38. Newell, S. Y., and Fallon, R. D. 1991. Toward a method for measuring instantaneous fungal growth rates in field samples. Ecology 72:1547-1559.

39. Nicholson, P., Doohan, F., Rezanoor, H. N., Simpson, D., Smith, P. H., Turner, A., and Weston, G. 1997. Detection and quantification of individual fungal species in Fusarium disease complexes of cereals by polymerase chain reaction (PCR). Cereal Res. Comm. 25:477-482.

40. Ochor, T. E., Trevathan, L. E., and King, S. B. 1987. Relationship of harvest date and host genotype to infection of maize kernels by Fusarium moniliforme. Plant Dis. 71:311-313.

41. Park, D. 1960. Antagonism-The background to soil fungi. Pages 148159 in: The Ecology of Soil Fungi. D. Parkinson and J. S. Waid, eds. Liverpool University Press, Liverpool, United Kingdom.

42. Pestka, J. J., and Bondy, G. S. 1994. Immunotoxic effects of mycotoxins. Pages 339-358 in: Mycotoxins in Grain: Compounds Other than Aflatoxin. J. D. Miller and H. L. Trenholm, eds. The American Phytopathological Society, St. Paul, MN.

43. Prelusky, D. B., Rotter, B. A., and Rotter, R. G. 1994. Toxicology of mycotoxins. Pages 359-403 in: Mycotoxins in Grain: Compounds Other than Aflatoxin. J. D. Miller and H. L. Trenholm, eds. The American Phytopathological Society, St. Paul, MN.

44. Ramakrishna, N., Lacey, J., and Smith, J. E. 1996. The effects of fungal competition on colonization of barley grain by Fusarium sporotrichiodes on T-2 toxin formation. Food Addit. Contam. 8:939-948.

45. Rehner, S. A., and Samuels, G. J. 1995. Molecular systematics of Hypocreales: A teleomorph gene, phylogeny and the status of their anamorphs. Can. J. Bot. 73:S816-S823.

46. Reid, L. M., Bolton, A. T., Hamilton, R. I., Woldemariam, T., and Mather, D. E. 1992. Effect of silk age on resistance of maize to Fusarium graminearum. Can. J. Plant Pathol. 14:293-298.

47. Reid, L. M., Hamilton, R. I., and Mather, D. E. 1996. Screening Maize for Resistance to Gibberella Ear Rot. Agric. Agri-Food Can. Tech. Bull. Publ. 196-5E.

48. Rheeder, J. P., Marasas, W. F. O., and van Wyk, P. S. 1990. Fungal associa- tions in corn kernels and effects on germination. Phytopathology 80:131-134. 49. Schaafsma, A. W., Miller, J. D., Savard, M. E., and Ewing, R. J. 1993. Ear rot development and mycotoxin production in corn in relation to inoculation method, corn hybrid, and species of Fusarium. Can. J. Plant Pathol. 15:185-192.

50. Seitz, L. M., and Bechtel, D. B. 1985. Chemical, physical, and microscopical studies of scab-infected hard red winter wheat. J. Agric. Food Chem. 33:373-377.

51. Shurtleff, M. C., ed. 1984. Compendium of Corn Diseases. The American Phytopathological Society, St. Paul, MN.

52. Sinha, R. C., and Savard, M. E. 1996. Comparison of immunoassay and gas chromatography methods for the detection of the mycotoxin deoxynivalenol in grain samples. Can. J. Plant Pathol. 18:233-236.

53. Sung, J., and Cook, R. J. 1981. Effect of water potential on reproduction and spore germination by Fusarium roseum 'Graminearum,' 'Culmorum,' and 'Avenaceum.' Phytopathology 71:499-504.

54. Sutton, J. C. 1982. Epidemiology of wheat head blight and maize ear rot caused by Fusarium graminearum. Can. J. Plant Pathol. 4:195-209.

55. Sutton, J. C., and Baliko, W. 1981. Methods for quantifying partial resistance to Gibberella zeae in maize ears. Can. J. Plant Pathol. 3:26-32.

56. Sutton, J. C., Baliko, W., and Liu, H. J. 1980. Fungal colonization and zearalenone accumulation in maize ears injured by birds. Can. J. Plant Sci. 60:453-461.

57. Tuite, J., Shaner, G., Rambo, G., Foster, J., and Caldwell, R. W. 1974. The gibberella ear rot epidemics of corn in Indiana in 1965 and 1972. Cereal Sci. Today 19:238-241.

58. Ullstrup, A. J. 1970. Methods for inoculating corn ears with Gibberella zeae and Diplodia maydis. Plant Dis. Rep. 54:658-662.

59. Vigier, B., Reid, L. M., Seifert, K. A., Stewart, D. W., and Hamilton, R. I. 1997. Distribution and prediction of Fusarium species associated with maize ear rot in Ontario. Can. J. Plant Pathol. 19:60-65.

60. Wicklow, D. T. 1981. Interference competition and the organization of fungal communities. Pages 351-375 in: The Fungal Community. D. R. Wicklow and G. C. Carrol, eds. Marcel Dekker, Inc., New York.

61. Wicklow, D. T. 1988. Patterns of fungal association within maize kernels harvested in North Carolina. Plant Dis. 72:113-115.

62. Wicklow, D. T., Horn, B. W., Shotwell, O., Hesseltine, C., and Caldwell, R. 1988. Fungal interference with Aspergillus flavus infection and aflatoxin contamination of maize grown in a controlled environment. Phytopathology 78:68-74.

63. Woods, D. M., and Duniway, J. M. 1986. Some effects of water potential on growth, turgor, and respiration of PShytophthora cryptogea and $\mathrm{Fu}$ sarium moniliforme. Phytopathology 76:1248-1254.

64. Young, J. C. 1995. Microwave-assisted extraction of the fungal metabolite ergosterol and total fatty acids. J. Agric. Food Chem. 43:2904-2910.

65. Zummo, N., and Scott, G. E. 1990. Cob and kernel infection by Aspergillus flavus and Fusarium moniliforme in inoculated field-grown maize ears. Plant Dis. 74:627-631.

66. Zummo, N., and Scott, G. E. 1992. Interaction of Fusarium moniliforme and Aspergillus flavus on kernel infection and aflatoxin contamination in maize ears. Plant Dis. 76:771-773. 